\title{
Menanamkan Sikap Moderasi Beragama Melalui Pendidikan Agama Kristen Di SMAN 1 Bintan Timur
}

\author{
Evans Dusep Dongoran', Johanes Waldes Hasugian², Josanti ${ }^{3}$, Alex Djuang Papay ${ }^{4}$ \\ ${ }^{1,3,4}$ Prodi Teologi, STT REAL Batam \\ ${ }^{2}$ Prodi Pendidikan Agama Kristen, STT Sumatera Utara \\ *evansdongoran@gmail.com
}

\begin{abstract}
Religious moderation is a religious attitude that is balanced between the practice of one's own religion and respect for the religious practices of other people with different beliefs. The attitude of religious moderation must be instilled from an early age among students, in the midst of the development of radical understanding among students. For Christian students, religious moderation is instilled through Christian education which is centered on Jesus Christ. So that through the example of Jesus, students can have a balanced attitude between loving God and others, having an attitude of tolerance and respecting differences Keywords: Religious Moderation Attitudes, Christian Education, Public High Schools, East Bintan
\end{abstract}

\begin{abstract}
Abstrak
Moderasi beragama adalah sikap beragama yang seimbang antara pengamalan agama sendiri dan penghormatan kepada praktik beragama orang lain yang berbeda keyakinan. Sikap Moderasi beragama harus ditanamkan sejak dini dikalangan pelajar, di tengah berkembangnya paham radikal di kalangan pelajar. Bagi pelajar Kristen moderasi beragama ditanamkan melalui pendidikan agama Kristen yang berpusat kepada Yesus Kristus. Sehingga melalui teladan Yesus para pelajar dapat memiliki sikap keseimbangan antara mengasihi Allah dan sesama, memiliki sikap toleransi dan menghargai perbedaan.

Kata kunci: Sikap Moderasi Beragama, Pendidikan Agama Kristen, Sekolah Menengah Umum, Bintan Timur
\end{abstract}

\section{PENDAHULUAN}

Pluralitas agama merupakan suatu kekayaan dan anugerah Tuhan yang dimiliki Indonesia. Kekayaan dan anugrah ini akan menjadi masalah ketika tidak dijaga dengan baik. Realitas pluralitas agama sering menjadi pemicu terjadinya gesekan ataupun konflik bagi bangsa Indonesia. Salah satu ancaman terbesar dalam memecah belah kita sebagai bangsa adalah konflik berlatar belakang agama. ${ }^{1}$ Konflik ini muncul oleh karena maraknya kelompok ekstrim dan radikal yang ingin mengganggu dan mengancam keutuhan NKRI. Pemahaman yang salah terhadap realitas keberagaman akan melahirkan sikap yang radikal dan intoleran terhadap pemeluk agama lain, sehingga perlu didasari dengan sikap saling menghormati dan toleransi dengan pemeluk agama lain. ${ }^{2}$ Paham agama yang ekstrim dan radikal ternyata tidak hanya terjadi dalam aspek sosial, politik, dan tokoh agama, melainkan juga terjadi di dunia pendidikan. ${ }^{3}$

Berkembangnya paham-paham semacam itu dapat menjadi ancaman bagi pelajar, yang adalah penerus bangsa. Harus ada upaya yang dilakukan untuk mencegah dan menetralisir paham-paham semacam itu. Dalam konteks pendidikan, upaya deradikalisasi dapat dilakukan melalui pendidikan agama. Pada mata pelajaran agama, nilai nilai deradikalisasi ditanamkan dengan cara mengajarkan jalan kebenaran tanpa menjelek-jelekan agama lain. Agama yang diajarkan harus sesuai dengan

${ }^{1}$ Beridiansyah Beridiansyah, "Kejahatan Terorisme Dan Ancaman Bagi Kedaulatan NKRI,” Jurnal Ilmu Kepolisian 11, no. 2 (2017): 8. Rojabi Azharghany, "Perdamaian Dan Multikulturalisme Di Indonesia (Strategi Dakwah Multikulturalisme Dalam Pertentangan Laten Radikalisme Dan Bias Konflik)," Jurnal Kopis: Kajian Penelitian dan Pemikiran Komunikasi Penyiaran Islam 1, no. 2 (2019): 28-47.

${ }^{2}$ Budi Ichwayudi and Moh Yardho, "Menangkal Potensi Radikalisme Pada Pemuda Melalui Dialog Lintas Agama: Analisis Terhadap Program Forum Kerukunan Umat Beragama Bagi Pemuda Lintas Agama Di Jawa Timur," n.d.

${ }^{3}$ Muhammad Saekan Muchith, "Radikalisme Dalam Dunia Pendidikan,” Addin 10, no. 1 (2016): 163. 
nilai-nilai Pancasila. Agama harus dapat mendudukan sebagai pilar kebangsaan, dengan maksud ajaran agama membuat manusia dapat bertoleransi dan mendukung satu sama lain dalam kehidupan berbangsa dan bernegara. ${ }^{4}$ Sementara itu, penelitian Ahnaf menunjukkan bahwa potensi radikalisasi di lingkungan pendidikan tidak terletak utamanya pada kurikulum pendidikan agama, tetapi lingkungan sekolah yang memungkinkan interaksi siswa dengan narasi radikal di luar ruang kelas. $^{5}$

Oleh karena itu, penulis merasa perlu mengadakan pembinaan kerohanian kepada pelajar Kristen di SMA Negeri 1 Bintan Timur, dalam mananamkan nilai-nilai moderasi beragama. Dengan harapan melaui pelayanan atau pengabdian kepada masyarakat ini, pelajar Kristen di SMAN 1 Bintan Timur dapat memahami apa itu moderasi beragama dan dapat menerapkan nilai-nilai moderasi beragama, saling menghargai dalam menjaga kerukunan antar umat beragama.

\section{Metode Penelitian}

Kegiatan pengabdian ini dilaksanakan di di SMAN 1 Bintan Timur. Dengan pendekatan adalah metode ceramah, tanya jawab, diskusi. Metode-metode yang digunakan ini sangat efektif dengan memberika penjelasan, memecahkan masalah yang sulit dipahami serta mendiskusikan topik moderasi beragama. Evaluasi ini lakukan di setiap sesi untuk melihat sejauh mana keterlibatan dan respon dari mitra terhadap kegiatan ini serta kendala-kendala yang hadapi sebelum dan sesudah menerima pembinaan dan materi dari narasumber. Pelaksanaan kegiatan pembinaan pada mitra/dosen dilaksanakan di dua kelompok kelas yang berbeda pada tanggal 15 \& 17 Januari 2020 secara tatap muka. Peserta yang mengikuti kegiatan ini berjumlah 25 orang.

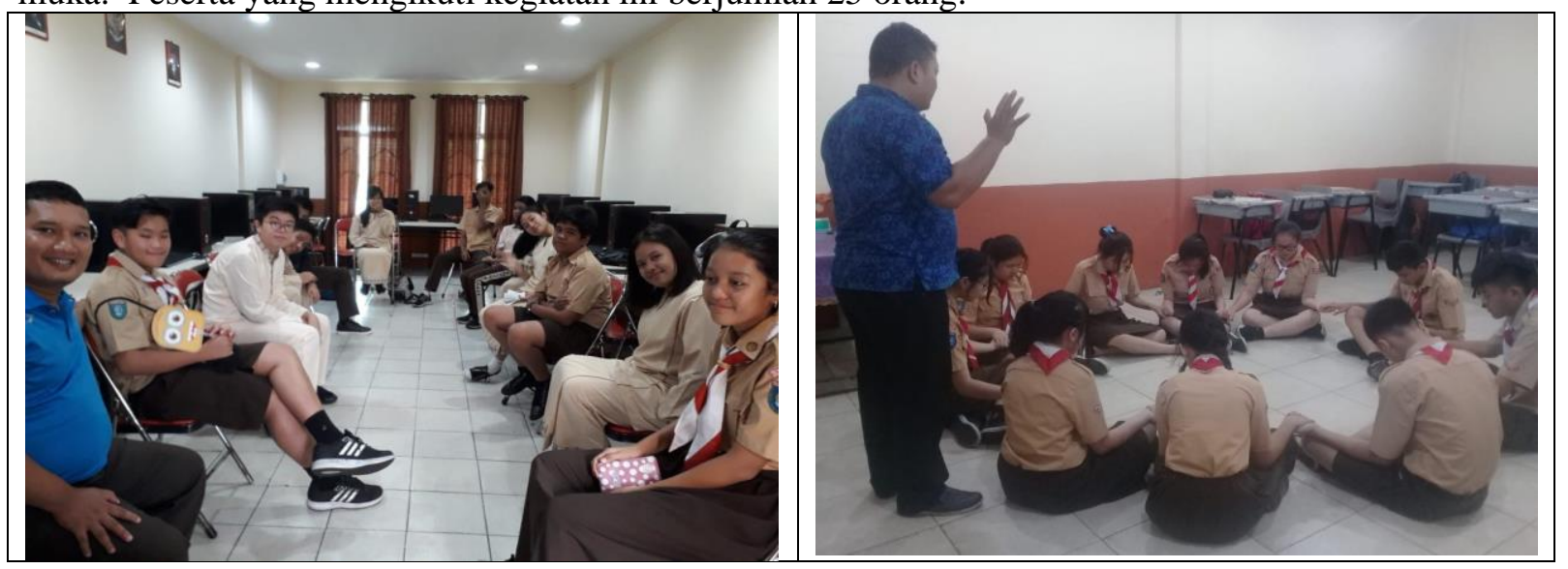

Gambar 1. Suasana Kegiatan Penyuluhan Moderasi Beragama Bersama Pelajar

\section{HASIL DAN PEMBAHASAN}

Pendidikan adalah cara terbaik untuk mengubah dan membentuk kehidupan karakter manusia, yang hal ini bersesuaian dengan UU No. 20 tahun 2003 tentang Sistem Pendidikan Nasional yang mengemukakan bahwa pendidikan adalah usaha sadar dan terencana untuk mewujudkan suasana belajar dan proses pembelajaran agar peserta didik secara aktif mengembangkan potensi dirinya untuk memiliki kekuatan spiritual keagamaaan, pengendalian diri, kepribadian, kecerdasan, akhlak mulia, serta keterampilan yang diperlukan dirinya, masyarakat, bangsa, dan negara. ${ }^{6}$

\footnotetext{
${ }^{4}$ Putri Hergianasari, "Konsep Deradikalisasi Pada Pendidikan Berbasis Pembelajaran Terpadu," Scholaria: Jurnal Pendidikan Dan Kebudayaan 9, no. 3 (2019): 239-244.

${ }^{5}$ Mohammad Iqbal Ahnaf, "Struktur Politik Dan Deradikalisasi Pendidikan Agama Bagi Anak Muda Di Indonesia,” Jurnal Pendidikan Islam 2, no. 1 (2013): 153-171.

${ }^{6}$ Republik Indonesia Undang-Undang, "No. 20 Tahun 2003 Tentang Sistem Pendidikan Nasional," Bandung: Citra Umbara (2003).
} 
Melalui pendidikan dapat mengajarkan dan membimbing manusia untuk lebih memahami realitas serta mampu menghadapi problem hidup dan kehidupan. Kesalahan dalam praktik pendidikan akan berakibat fatal bagi kelangsungan kehidupan bangsa ${ }^{7}$ Proses pendidikan harus bersih dari unsur yang bertentangan dengan tujuan pendidikan terlebih dari paham radikalisme yang sama sekali tidak menguntungkan bagi bangsa ditambah lagi sangat berpotensi menimbulkan konflik dan perpecahan bagi bangsa.

\section{MODERASI BERAGAMA}

\section{Pengertian Moderasi Beragama}

Kata "moderasi" berasal dari bahasa Latin moderatio, yang berarti ke-sedang-an (tidak kelebihan dan tidak kekurangan). Kata itu juga berarti penguasaan diri (dari sikap sangat kelebihan dan kekurangan). Kamus Besar Bahasa Indonesia (KBBI) menyediakan dua pengertian kata moderasi, yakni: 1. pengurangan kekerasan, dan 2 penghindaran keekstreman. Jika dikatakan, "orang itu bersikap moderat", kalimat itu berarti bahwa orang itu bersikap wajar, biasa-biasa saja, dan tidak ekstrem. Merujuk kedua kata itu, moderasi beragama dapat berarti sebagai sikap mengurangi kekerasan, atau menghindari keekstreman dalam praktik beragama. ${ }^{8}$

Moderasi beragama harus dipahami sebagai sikap beragama yang seimbang antara pengamalan agama sendiri (eksklusif) dan penghormatan kepada praktik beragama orang lain yang berbeda keyakinan (inklusif). ${ }^{9}$ Moderasi beragama sangat erat terkait dengan menjaga kebersamaan dengan memiliki sikap 'tenggang rasa', sebuah warisan leluhur yang mengajarkan kita untuk saling memahami satu sama lain yang berbeda dengan kita. ${ }^{10}$ Dalam tradisi Kristen,

\section{Penting Moderasi Beragama}

Moderasi beragama pada dasarnya mencari persamaan dan bukan mempertajam perbedaan. Ada tiga alasan utama pentingnya moderasi beragama, yaitu: pertama, salah satu esensi kehadiran agama adalah untuk menjaga martabat manusia sebagai makhluk mulia ciptaan Tuhan, termasuk menjaga untuk tidak menghilangkan nyawanya. Moderasi beragama menjunjung tinggi nilai kemanusiaan; kedua, ribuan tahun setelah agama-agama lahir, manusia semakin bertambah dan beragam, bersuku-suku, berbangsa-bangsa, beraneka warna kulit, tersebar di berbagai negeri dan wilayah. Agama juga ikut berkembang sehingga melahirkan penafsir-penafsir, sehingga teks kitab suci menjadi multi tafsir; ketiga, khusus dalam konteks Indonesia, moderasi beragama diperlukan sebagai strategi kebudayaan kita dalam merawat keindonesiaan. Sebagai bangsa yang sangat heterogen, sejak awal para pendiri bangsa sudah berhasil mewariskan satu bentuk kesepakatan dalam berbangsa dan bernegara, yakni Pancasila dalam Negara Kesatuan Republik Indonesia, yang telah nyata berhasil menyatukan semua kelompok agama, etnis, bahasa, dan budaya. ${ }^{11}$

\section{Prinsip Dasar Moderasi Beragama}

Prinsip dasar moderasi ialah adil dan berimbang. ${ }^{12}$ Salah satu prinsip dasar dalam moderasi beragama adalah selalu menjaga keseimbangan diantara dua hal, misalnya keseimbangan antara akal

\footnotetext{
${ }^{7}$ Muchith, "Radikalisme Dalam Dunia Pendidikan."

${ }^{8}$ Achmad Syahid, "Pembawaan Normatif, Kebijakan Inklusif Dan Legasi Prestasi”" (Rehobot Literature, n.d.).

9 Tim Penyusun Kementerian Agama, MODERASI BERAGAMA (Jakarta: Badan Litbang dan Diklat Kementerian Agama RI, 2019).

${ }^{10}$ Agus Akhmadi, "Moderasi Beragama Dalam Keragaman Indonesia Religious Moderation in Indonesia ' S Diversity,” Jurnal Diklat Keagamaan 13, no. 2 (2019): 45-55.

${ }^{11}$ Agama, MODERASI BERAGAMA.

12 Ibid.
} 
dan wahyu, antara jasmani dan rohani antara hak dan kewajiban, antara kepentingan individu dan kemaslahatan komunal, antara keharusan dan kesukarelaan, antar teks agama dan ijtihad tokoh agama, antara gagasan ideal dan kenyataan, serta keseimbangan antara masa lalu dan masa depan. Prinsip yang kedua, keseimbangan, adalah istilah untuk menggambarkan cara pandang, sikap, dan komitmen untuk selalu berpihak pada keadilan, kemanusiaan, dan persamaan. Kecenderungan untuk bersikap seimbang bukan berarti tidak punya pendapat, ${ }^{13}$ namun mengambil sikap yang tidak berat sebelah terhadap orang lain, bahkan yang berbeda sekalipun secara realitas.

\section{Moderasi Beragama dalam Pendidikan Agama Kristen}

Sutrisno mengemukakan bahwa dalam tradisi Kristen, moderasi beragama menjadi cara pandang untuk menengahi ekstremitas tafsir ajaran Kristen yang dipahami sebagian umatnya. Salah satu kiat untuk memperkuat moderasi beragama adalah melakukan interaksi semaksimal mungkin antara agama yang satu dengan agama yang lain, antara aliran yang satu dengan aliran yang lain dalam internal umat beragama. ${ }^{14}$

Dalam pendidikan agama Kristen Alkitab atau firman Tuhan menjadi sumber dalam pendidikan yang berpusat kepada Kristus. Werner G. Graendorf berpendapat bahwa pendidikan Kristen adalah pendidikan yang didasarkan pada kitab suci, dikuasai oleh Roh Kudus, dan berpusatkan Kristus. Dimana proses belajar mengajar disesuaikan dengan tingkat perkembangan masing-masing individu, serta sistem mengajar kontemporer yang melaluinya seseorang dapat mengenal dan mengalami rencana dan maksud Allah, melalui Yesus Kristus dalam setiap aspek kehidupannya, serta mempersiapkan mereka bagi pelayanan yang efektif, yang berfokuskan pada Kristus, sang Guru Agung. ${ }^{15}$

Moderasi beragama sangat jelas dalam ajaran Tuhan Yesus di dalam hukum yang terutama "Mengasihi Allah dan Mengasihi Sesama" dalam Matius 22:37-39 "Jawab Yesus kepadanya: "Kasihilah Tuhan, Allahmu, dengan segenap hatimu dan dengan segenap jiwamu dan dengan segenap akal budimu. Itulah hukum yang terutama dan yang pertama. Dan hukum yang kedua, yang sama dengan itu, ialah: Kasihilah sesamamu manusia seperti dirimu sendir". Adanya keseimbangan antara Hubungan kita dengan Allah dan Hubungan kita dengan sesama. Keseimbangan antara mengasihi Allah dan mengasihi manusia harus dapat berjalan bersamaan dimana jika kita mengasihi Allah, dibuktikan dengan kita mengasihi sesama manusia.

Moderasi beragama juga terdapat dalam konsep Garam dan terang Dunia yang diajarkan Yesus dalam Matius 5: 13 "Kати adalah garam dunia" dan ayat 14 Kamu adalah terang dunia'. Kehidupan orang percaya ditengah-tengah dunia harus dapat memberikan dampak yang baik bagi sekitarnya. Garam yang putih dan mengkilap saat tertimpa matahari menghubungkan identitas dirinya dengan simbol kemurnian dan Garam memberikan cita rasa tertentu kepada banyak hal ${ }^{16}$ Demikian pelajar Kristen dalam membangun sikap toleransi tidak boleh kehilangan identitasnya sebagai umat Tuhan dan memberikan dampak yang positif bagi lingkungannya.

Moderasi beragama juga terdapat dalam ajaran Yesus tentang menghormati dan menerima orang asing ketika Yesus berbincang dengan perempuan Samaria Yohanes 4:9. Pada saat itu orang Yahudi sangat "tabu" untuk duduk dan berbincang dengan orang Samaria, karena adat istiadat dan kepercayaan yang mereka miliki. Namun Yesus merobohkan sikap intoleran yang dimiliki orang

\footnotetext{
${ }^{13}$ Ibid.

${ }^{14}$ Edy Sutrisno, “Aktualisasi Moderasi Beragama Di Lembaga Pendidikan,” Jurnal Bimas Islam 12, no.
} 2 (2019): 323-348.

${ }^{15}$ Werner C. Graendorf, Introduction to Biblical Christian Education, (Chicago: Moody Press), p. 16.

${ }^{16}$ William Barclay, Pemahaman Alkitab Setiap Hari: Matius Ps. 1-10, (Jakarta: BPK Gunung Mulia, 1991), 199-200 
Yahudi. Tindakan Yesus dengan berbincang dengan perempuan samaria menandakan Yesus menerima dan menghormati keberadaan perempuan samaria.

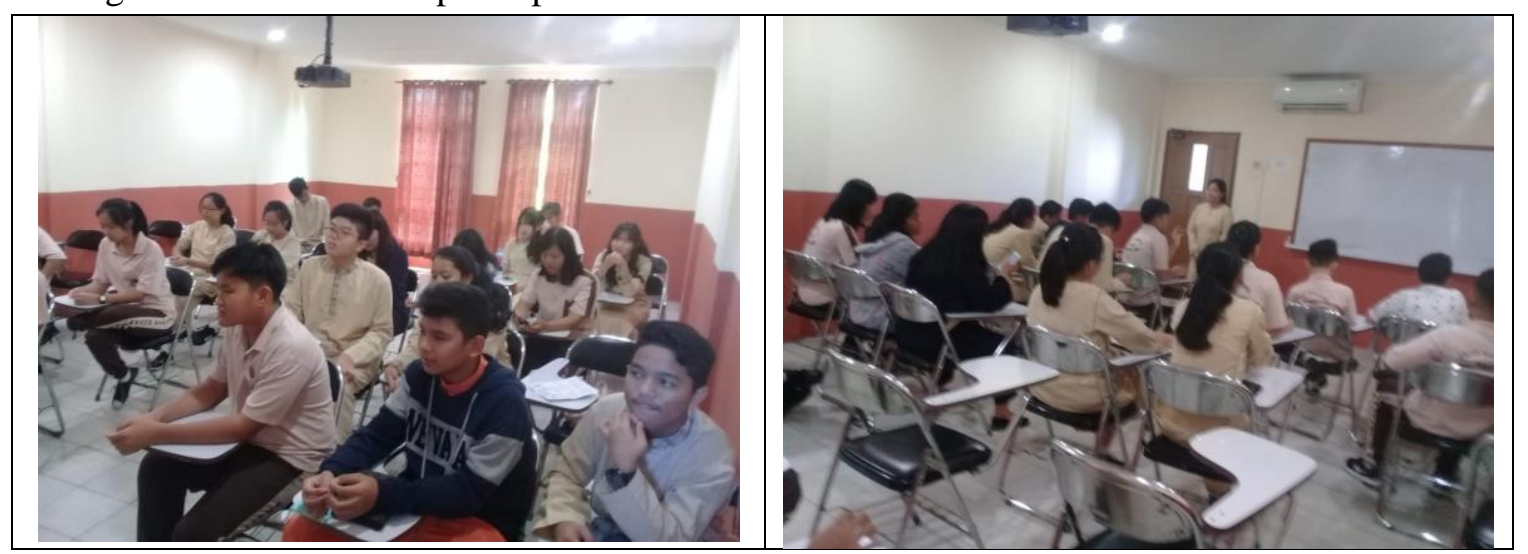

Gambar 2. Fokus Group Diskusi para Pelajar Membahas Moderasi Beragama

\section{SIMPULAN}

Dalam kemajemukan agama sangat diperlukan moderasi beragama, dalam krangka menjaga kerukuan antar dan inter umat beragama. Dunia pendidikan adalah tempat yang paling tepat dalam menanamkan nilai-nilai moderasi beragama. Pelajar harus diberikan pendidikan yang benar sehingga menjadikan mereka memiliki karakter yang berguna bagi bangsa dan negara.

Para pelajar Kristen harus ditanamkan pemahaman moderasi beragama yang benar. Sehingga memiliki sikap yang baik dalam masyarakat, seperti keseimbangan antara mengasihi Allah dan mengasihi sesama, membangun toleransi umat beragama tanpa harus kehilangan identitasnya, serta menerima dan menghargai realitas perbedaan dalam relasinya dengan masyarakat, termasuk teman di sekolahnya.

\section{DAFTAR PUSTAKA}

Agama, Tim Penyusun Kementerian. MODERASI BERAGAMA. Jakarta: Badan Litbang dan Diklat Kementerian Agama RI, 2019.

Ahnaf, Mohammad Iqbal. "Struktur Politik Dan Deradikalisasi Pendidikan Agama Bagi Anak Muda Di Indonesia." Jurnal Pendidikan Islam 2, no. 1 (2013): 153-171.

Akhmadi, Agus. "Moderasi Beragama Dalam Keragaman Indonesia Religious Moderation in Indonesia' S Diversity." Jurnal Diklat Keagamaan 13, no. 2 (2019): 45-55.

Azharghany, Rojabi. "Perdamaian Dan Multikulturalisme Di Indonesia (Strategi Dakwah Multikulturalisme Dalam Pertentangan Laten Radikalisme Dan Bias Konflik)." Jurnal Kopis: Kajian Penelitian dan Pemikiran Komunikasi Penyiaran Islam 1, no. 2 (2019): 28-47.

Beridiansyah, Beridiansyah. "Kejahatan Terorisme Dan Ancaman Bagi Kedaulatan NKRI." Jurnal Ilmu Kepolisian 11, no. 2 (2017): 8.

Hergianasari, Putri. "Konsep Deradikalisasi Pada Pendidikan Berbasis Pembelajaran Terpadu." Scholaria: Jurnal Pendidikan Dan Kebudayaan 9, no. 3 (2019): 239-244.

Ichwayudi, Budi, and Moh Yardho. "Menangkal Potensi Radikalisme Pada Pemuda Melalui Dialog Lintas Agama: Analisis Terhadap Program Forum Kerukunan Umat Beragama Bagi Pemuda Lintas Agama Di Jawa Timur," n.d.

Muchith, Muhammad Saekan. "Radikalisme Dalam Dunia Pendidikan.” Addin 10, no. 1 (2016): 163. Sutrisno, Edy. "Aktualisasi Moderasi Beragama Di Lembaga Pendidikan.” Jurnal Bimas Islam 12, no. 2 (2019): 323-348.

Syahid, Achmad. "Pembawaan Normatif, Kebijakan Inklusif Dan Legasi Prestasi." Rehobot Literature, n.d.

Undang-Undang, Republik Indonesia. "No. 20 Tahun 2003 Tentang Sistem Pendidikan Nasional." Bandung: Citra Umbara (2003). 